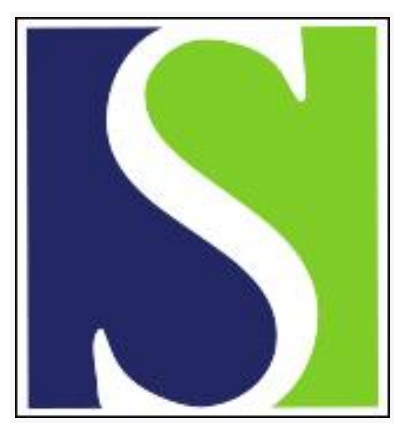

Scand J Work Environ Health 1985;11(1):7-13

https://doi.org/10.5271/sjweh.2261

Issue date: Feb 1985

Cancer incidence among workers exposed to radon and thoron daughters at a niobium mine.

by Solli HM, Andersen A, Stranden E, Langard S

This article in PubMed: www.ncbi.nlm.nih.gov/pubmed/2986282

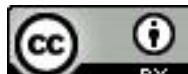




\title{
Cancer incidence among workers exposed to radon and thoron daughters at a niobium mine
}

\author{
by Hans $\mathrm{M}$ Solli, MD, ${ }^{1}$ Aage Andersen, ${ }^{2}$ Erling Stranden, $\mathrm{PhD},{ }^{3}$ Sverre Langård, $\mathrm{MD}, \mathrm{MSc}{ }^{1}$
}

\begin{abstract}
SOLLI HM, ANDERSEN A, STRANDEN E, LANGÅRD S. Cancer incidence among workers exposed to radon and thoron daughters at a niobium mine. Scand $J$ Work Environ Health 11 (1985) 7-13. The aim of this study was to investigate the incidence of cancer among 318 male employees of a niobium mining company which was only operated between 1951 and 1965. Many of the workers, especially underground miners, were exposed to the daughters of radon and thoron and also to thorium. The accumulated doses to the workers from short-lived radon and thoron daughters in the mine atmosphere were assessed to be relatively low; up to 300 working-level months. During the follow-up period 1953-1981, 24 new cases of cancer were observed compared to an expected number of 22.8 . Twelve cases of lung cancer had occurred versus 3.0 expected. Among the 77 miners, 9 cases of lung cancer were observed against 0.8 expected. Associations between the occurrence of lung cancer and exposure to alpha radiation and smoking were found. For the radon and thoron daughter exposure, about 50 excess cases per million person-years at risk per working-level month were observed.
\end{abstract}

Key terms: cohort study, ionizing radiation, lung cancer, mortality, occupational hazards, risk estimates, thorium.

Among miners the cancer hazard related to exposure to the short-lived daughters formed by the radioactive decay of the radon isotope ${ }^{222} \mathrm{Rn}$, called radon, has been extensively studied $(1,4,8,16)$. The possible risks related to exposure to the daughters of another radon isotope, ${ }^{222} \mathrm{Rn}$, called thoron, are not so well known (20).

The purpose of the present investigation was to study the incidence of cancer in a population of workers known to have been exposed to radon and thoron daughters.

The exposure took place at a mine where niobium was produced between 1953 and 1965. As far as niobium is concerned, no present evidence indicates that this element is carcinogenic in man. However, this lack of evidence is based on tests with relatively few niobium compounds, mainly the pentachloride and the niobates (19).

\section{Materials and methods}

\section{The mine}

The Söve mine was located in the Fen area at Ulefoss, a small village in Southeastern Norway. Construction started in 1951. From 1953 to 1957 niobium was produced mainly from open cast mining. In 1957 an

\footnotetext{
1 Department of Occupational Medicine, Telemark Sentralsjukehus, Porsgrunn, Norway.

2 Cancer Registry of Norway, Oslo, Norway.

3 National Institute of Radiation Hygiene, Oslo, Norway.
}

Reprint requests to: Dr S Langård, Department of Occupational Medicine, Telemark Sentralsjukehus, N-3900 Porsgrunn, Norway. underground mine was excavated to a depth of $135 \mathrm{~m}$ below ground level. This mine became the main provider of raw material until the works were closed down in 1965.

There were five main activities in the mining works. They were mining; washing, crushing and sorting; ferroniobium production; maintenance work, both on the surface and underground; and office work.

In addition to $0.3-0.5 \%$ niobium oxide, the mined rocks contained ${ }^{238} \mathrm{U}$ (uranium) and ${ }^{232} \mathrm{Th}$ (thorium). The concentration of uranium was $0.3-2$ $\mathrm{ppm}$ and that of thorium was $50-300 \mathrm{ppm}$ (21). The average concentration of ${ }^{232} \mathrm{Th}$ in the rocks was $2-10 \mathrm{ppm}$. In the radioactive decay series of ${ }^{238} \mathrm{U}$ and ${ }^{232} \mathrm{Th}$, radon and thoron, respectively, are found.

\section{Study design}

The names of the employees were obtained from three different sources, ie, the company's payroll, two records at the local office of the National Insurance Administration, and a letter of congratulation sent by the miners to one of their colleagues. From these three sources it was possible to reconstruct a complete list of employees in every year with the exception of the construction years 1951 and 1952 and the production years 1955-1956. Three hundred and twenty-two males were identified. From an analysis of the employment numbers in the company's payroll, it can be assumed that about 40 men have not been traced for these four years. It can also be inferred that all these men had been employed for a rather short time, ie, from a few days to less than two years. The list of employees having worked for two 
years or more is complete. Four more workers had to be excluded because of incomplete data. The study group, therefore, consisted of $318 \mathrm{men}$, born between 1889 and 1947.

Information on the complete occupational history, work at the mine, the type of work before and after employment at the mine, and asbestos exposure was obtained for each individual. Information on tobacco usage was also recorded. The information was obtained in the following way: 26 men were interviewed personally; 195 employees filled out a questionnaire, and about $60 \%$ of the 195 were afterwards contacted by telephone for supplementary information; 16 were interviewed by telephone alone. Three former workers could not be traced. No one refused to give information.

For all the deceased members of the cohort except one, information on exposure was obtained from close relatives and/or colleagues.

The Norwegian Cancer Registry has acquired information on all new cases of cancer in the country since 1953. The registration is based on compulsory reporting from all the hospitals and pathological laboratories. The material from the mine was matched against that of the Cancer Registry with the aid of the national birth numbers.

All members of the study group were observed from the beginning of 1953 or, in the case of later first employment. from the time they were appointed at the mine. They were observed until the end of 1981 or to the time of death. The study was based on a comparison of observed and expected total mortality and incidence of cancer, the method described by Pedersen et al (18) and Langård \& Norseth (13) being used. This method includes calculation of the risk of getting cancer for each person separately; it involves the use of age-specific incidence rates of cancer in the Norwegian male population $(6,7)$.

It was assumed that the observed numbers of cancer cases followed the Poisson distribution with the expected numbers as the modes. Poisson distributions were used for significance testing. The test used has been described by Axelson (3).

After the identity of the cancer cases was disclosed, the medical files of the lung cancer cases were obtained, with the exception of one file which could not be found.

\section{Exposure history}

The cohort members were mainly recruited from industry and agriculture. Some were school dropouts. The 77 underground miners in the cohort were mainly recruited from the building and construction industry, but about one-fourth of them also had previous experience in mining and tunnel work.

The employment time and job description at the mine could be found in the company records for almost all employees in the study group. The information was confirmed and supplemented by the questionnaires and the interviews. For the workers who had different jobs at the mine, the occupation in which the worker spent the longest time was used to describe his job.

The work time in months at the different sites in the mining works was assessed from a combination of the company records and the recollection of the workers themselves or their colleagues.

\section{Assessment of exposure}

Asbestos was rarely used at the mine, and only in the repair of machinery. An assessment of exposure to tobacco and radon and thoron daughters was attempted.

Tobacco. Information about the degree and type of tobacco usage was obtained from all but 5 of the 318 employees. For the deceased members of the cohort, the information was not so exact, but an estimate was made of how many years they had smoked, the type of smoking (ie, pipe, cigarettes or both), and quantity (either grams/week or cigarettes/day). Based on these data, a lifetime dose in grams was calculated for each of them up to the end of 1981.

The cohort was grouped into the following three categories: never or light smokers (up to a lifetime dose of $20000 \mathrm{~g}$ ), medium smokers (from $20000 \mathrm{~g}$ up to $200000 \mathrm{~g}$ ), and heavy smokers (more than a 200 000-g lifetime dose).

Radon and thoron daughters. The National Institute of Radiation Hygiene performed measurements of the alpha activity in the air in the underground mine in 1959 (unpublished). From the basic data of these measurements, the short-lived alpha activity concentrations in the mine air were assessed in terms of working level (WL) ${ }^{4}$ (table 1).

The alpha activity was also measured in 1959 in the ferroniobium factory and in the washing plant. The activity of the radon daughters was found to be less than $0.02 \mathrm{WL}$ in both places. Thoron daughters were not measured.

The accumulated dose of alpha radiation to the individual employee was calculated separately on the basis of information about the underground worktime in months and the mean levels shown in table 1. For all other sites in the works the radiation level was considered to be zero.

The International Commission on Radiological Protection (ICRP) recommends a conversion factor from working-level months (WLM) ${ }^{4}$ to an effective

\footnotetext{
${ }^{4}$ One working level (WL) is any combination of the shortlived decay products of radon or thoron per liter of air which will result in the ultimate emission of $1.3 \times 10^{5}$ $\mathrm{MeV}$ of alpha-particle energy. A working-level month (WLM) results from exposure to a concentration of decay products in air of $1 \mathrm{WL}$ for an average working month of $170 \mathrm{~h}$.
} 
dose equivalent of $10 \mathrm{mSv} / \mathrm{WLM}$ for radon daughters and $3.4 \mathrm{mSv} / \mathrm{WLM}$ for thoron daughters (10). For this reason one cannot simply add WLM from thoron daughters to WLM from radon daughters to get a total exposure level. The exposure must be weighed according to the aforementioned conversion factors. This procedure was carried out when the total dose of inhaled alpha activity was calculated for the workers. These dose assessments made it possible, with reasonable confidence, to subdivide the cohort into five exposure categories.

The employees' place of residence at the time they were employed at the mine was recorded. No measurements or assessments of radiation in the houses of the employees were made.

All employment classifications, exposure characterizations, and subdivision into categories were done before the cancer cases were identified.

\section{Results}

The numbers of deaths and cancer cases in the population exposed to radiation and other hazardous factors are presented as ratios between expected and observed numbers of deaths and cancer cases. The population was followed from 1953 to the end of 1981.

Table 2 presents the overall mortality and incidence of cancer in the whole cohort and in different occupations. During the follow-up period 78 deaths had occurred versus 67.86 expected. The total num- ber of observed cancer cases was 24 against 22.8 expected.

The 24 cancer cases were distributed as follows: 12 in the lung, 2 in the prostate, 2 in the large intestine, and 2 were leukemias. Furthermore, there was one in each of the following locations: the hypopharynx, the esophagus, the stomach, the pancreas, the kidney, and the central nervous system.

There were two cases of leukemia versus $0.7 \mathrm{ex}-$ pected (not presented in the tables). Both of these workers had only been employed in the washing plant and were not characterized as radiation exposed. One of them had worked mainly at the stone mill for nine years and had been exposed to dust the whole time. The other had been employed for only eight months.

The distribution of the lung cancer cases among the different occupations is presented in table 3 . Nine cases of lung cancer were observed in the 77 miners, against 0.81 expected.

The expected number of lung cancer cases in the whole study group, based on the risk in the average

Table 1. Measurements of radon and thoron daughters in the Söve mine in 1959.

\begin{tabular}{lcc}
\hline Level & $\begin{array}{c}\text { Radon } \\
\text { daughters } \\
(\mathrm{WL})\end{array}$ & $\begin{array}{c}\text { Thoron } \\
\text { daughters }\end{array}$ \\
$(\mathrm{WL})$
\end{tabular}

a See footnote 4 in the text for an explanation of WL.

Table 2. Observed $(O)$ and expected $(E)$ numbers of overall mortality and all cancer cases in the study population by occupation at the mine.

\begin{tabular}{|c|c|c|c|c|c|c|}
\hline \multirow{2}{*}{$\begin{array}{l}\text { Occupation } \\
\text { at the mine }\end{array}$} & \multirow{2}{*}{$\begin{array}{l}\text { Number of } \\
\text { employees }\end{array}$} & \multicolumn{2}{|c|}{ All deaths } & \multicolumn{2}{|c|}{ All cancers } & \multirow{2}{*}{$\begin{array}{l}\text { Person-years } \\
(1953-1981)\end{array}$} \\
\hline & & 0 & $E$ & 0 & $E$ & \\
\hline Miners & 77 & 26 & $17.83^{\star}$ & 12 & $5.52^{*}$ & 1717.0 \\
\hline Washing plant workers & 38 & 8 & 9.47 & 5 & 3.22 & 941.0 \\
\hline Ferroniobium workers & 16 & 5 & 4.38 & 1 & 1.50 & 376.5 \\
\hline Maintenance & 158 & 33 & 28.59 & 6 & 9.98 & 3824.5 \\
\hline $\begin{array}{l}\text { Clerical and administrative } \\
\text { staff }\end{array}$ & 29 & 6 & 7.59 & - & 2.59 & 732.0 \\
\hline Total & 318 & 78 & 67.86 & 24 & 22.81 & 7591.0 \\
\hline
\end{tabular}

$* p<0.05$.

Table 3. Observed $(O)$ and expected $(E)$ numbers of lung cancers among the occupations at the mine.

\begin{tabular}{|c|c|c|c|c|c|}
\hline $\begin{array}{l}\text { Occupation } \\
\text { at the mine }\end{array}$ & $\begin{array}{l}\text { Number of } \\
\text { employees }\end{array}$ & Observed & Expected & $O: E$ & $\begin{array}{l}\text { Person-years } \\
(1953-1981) \\
\end{array}$ \\
\hline Miners & 77 & 9 & 0.81 & $11.11^{*}$ & 1717.0 \\
\hline Washing plant workers & 38 & 1 & 0.41 & 2.44 & 941.0 \\
\hline Ferroniobium workers & 16 & - & 0.16 & . & 376.5 \\
\hline Maintenance & 158 & 2 & 1.24 & 1.61 & 3824.5 \\
\hline $\begin{array}{l}\text { Clerical and administrative } \\
\text { staff }\end{array}$ & 29 & - & 0.33 & . & 732.0 \\
\hline Total & 318 & 12 & 2.96 & $4.05^{*}$ & 7591.0 \\
\hline
\end{tabular}

$* p<0.001$ 
Table 4. Observed $(O)$ and expected $(E)$ numbers of lung cancers in three categories of tobacco exposure based on assessed lifetime dose up to the end of 1981.

\begin{tabular}{|c|c|c|c|c|c|}
\hline Category & $\begin{array}{l}\text { Number of } \\
\text { employees }\end{array}$ & Observed & Expected & $O: E$ & $\begin{array}{l}\text { Person-years } \\
(1953-1981)\end{array}$ \\
\hline $\begin{array}{l}\text { Non or light smokers } \\
\text { (Up to } 20000 \text { g/lifetime) }\end{array}$ & 58 & - & 0.50 & . & 1397.0 \\
\hline $\begin{array}{l}\text { Medium smokers (from } \\
20000 \mathrm{~g} \text { to } 200000 \mathrm{gl} \\
\text { lifetime) }\end{array}$ & 190 & 5 & 1.57 & $3.18^{\star}$ & 4514.5 \\
\hline $\begin{array}{l}\text { Heavy smokers ( } 200000 \text { or } \\
\text { more g/lifetime) }\end{array}$ & 65 & 7 & 0.88 & $7.95^{\star *}$ & 1587.0 \\
\hline Unknown & 5 & - & 0.01 & . & 92.5 \\
\hline Total & 318 & 12 & 2.96 & $4.05^{\star \star}$ & 7591.0 \\
\hline
\end{tabular}

${ }^{*} p<0.05, * * p<0.001$.

Table 5. Observed $(O)$ and expected $(E)$ numbers of lung cancers in five categories of cumulated alpha activity exposure in working-level months (WLM). ${ }^{a}$

\begin{tabular}{lccccc}
\hline Category & $\begin{array}{c}\text { Number of } \\
\text { employees }\end{array}$ & Observed & Expected & O:E & $\begin{array}{r}\text { Person-years } \\
(1953-1981)\end{array}$ \\
\hline Nonexposed & 194 & - & 1.73 & & 4622.0 \\
$1-19$ WLM & 58 & 3 & 0.50 & $6.0^{*}$ & 1342.5 \\
$20-79$ WLM & 6 & 2 & 0.58 & $6.90^{* *}$ & 1311.5 \\
$80-119$ WLM & 7 & 3 & 0.07 & $28.57^{* *}$ & 146.5 \\
120 or more WLM & 318 & 12 & 2.96 & $37.50^{* \star}$ & 168.5 \\
\hline Total & $-5.05^{* * *}$ & 7591.0 \\
\hline
\end{tabular}

a For an explanation of working-level months see footnote 4 in the text.

* $p<0.05,{ }^{* *} p<0.01,{ }^{* * *} p<0.001$.

Table 6. The lung cancer cases (International Classification of Diseases codes 162-163).

\begin{tabular}{|c|c|c|c|c|c|c|}
\hline \multirow{2}{*}{$\begin{array}{l}\text { Case } \\
\text { number }\end{array}$} & \multirow{2}{*}{$\begin{array}{l}\text { Exposure before } \\
\text { employment at mine }\end{array}$} & \multirow{2}{*}{$\begin{array}{l}\text { Period } \\
\text { employed } \\
\text { at mine }\end{array}$} & \multicolumn{2}{|c|}{ Exposure at mine } & \multirow{2}{*}{$\begin{array}{l}\text { Tobacco } \\
\text { consumption }{ }^{6}\end{array}$} & \multirow{2}{*}{$\begin{array}{l}\text { Years from } \\
\text { start of } \\
\text { employment } \\
\text { to diagnosis }\end{array}$} \\
\hline & & & Main activity & Exposure $^{a}$ & & \\
\hline 1 & None & $1951-1965$ & Mining & $\begin{array}{l}\text { WLM } 140 \\
\text { Dust exposure } 9 \text { years }\end{array}$ & $\begin{array}{l}75-100 \mathrm{~g} \text { (cigarettes) } \\
\text { week }\end{array}$ & 25 \\
\hline 2 & None & $1952-1962$ & $\begin{array}{l}\text { Washing and } \\
\text { sorting }\end{array}$ & $\begin{array}{l}\text { WLM } 6 \\
\text { No dust exposure }\end{array}$ & $\begin{array}{l}100-150 \mathrm{~g} \text { (pipe and } \\
\text { cigarettes)/week }\end{array}$ & 25 \\
\hline 3 & $\begin{array}{l}\text { Thoron daughter } \\
\text { exposure } 1917-1926\end{array}$ & $1953-1961$ & Mining & $\begin{array}{l}\text { WLM } 51 \\
\text { Dust exposure } 8 \text { years }\end{array}$ & $50 \mathrm{~g}$ (pipe)/week & 14 \\
\hline 4 & 7 years' tunnel work & $1953-1965$ & Mining & $\begin{array}{l}\text { WLM } 140 \\
\text { Dust exposure } 11 \text { years }\end{array}$ & $\begin{array}{l}50 \mathrm{~g} \text { (pipe)/week } \\
\text { until } 1970\end{array}$ & 25 \\
\hline 5 & $\begin{array}{l}1 \text { year's asbestos } \\
\text { exposure }\end{array}$ & $1953-1954$ & Maintenance & $\begin{array}{l}\text { WLM } 13 \\
\text { No dust exposure }\end{array}$ & $100 \mathrm{~g}$ (pipe)/week & 28 \\
\hline 6 & 2 years' tunnel work & $1954-1965$ & Mining & $\begin{array}{l}\text { WLM } 136 \\
\text { Dust exposure } 6 \text { years }\end{array}$ & $75 \mathrm{~g}$ (cigarettes)/week & 14 \\
\hline 7 & None & $1954-1965$ & Mining & $\begin{array}{l}\text { WLM } 66 \\
\text { Dust exposure } 5 \text { years }\end{array}$ & $100 \mathrm{~g}$ (cigarettes)/week & 27 \\
\hline 8 & $\begin{array}{l}5 \text { years' tunnel work } \\
3 \text { years' foundry work } \\
\text { (asbestos exposure) }\end{array}$ & $1954-1962$ & Mining & $\begin{array}{l}\text { WLM } 48 \\
\text { Dust exposure } 9 \text { years }\end{array}$ & $\begin{array}{l}50-150 \mathrm{~g} \text { (pipe and } \\
\text { cigarettes)/week }\end{array}$ & 27 \\
\hline 9 & None & $1955-1962$ & Mining & $\begin{array}{l}\text { WLM } 91 \\
\text { Dust exposure } 7 \text { years }\end{array}$ & $75 \mathrm{~g}$ (cigarettes)/week & 19 \\
\hline 10 & None & $1958-1962$ & Mining & $\begin{array}{l}\text { WLM } 13 \\
\text { Dust exposure } 4 \text { years }\end{array}$ & $125 \mathrm{~g}$ (pipe)/week & 10 \\
\hline 11 & $\begin{array}{l}\text { Machinist } 10 \text { years } \\
\text { (asbestos exposure) }\end{array}$ & $1958-1965$ & $\begin{array}{l}\text { Maintenance } \\
\text { (Inechanic) }\end{array}$ & $\begin{array}{l}\text { WLM } 89 \\
\text { Dust exposure } 2 \text { years }\end{array}$ & $125 \mathrm{~g}$ (cigarettes)/week & 21 \\
\hline 12 & 20 years' mining & $1961-1964$ & Mining & $\begin{array}{l}\text { WLM } 37 \\
\text { Dust exposure } 2 \text { years }\end{array}$ & $150 \mathrm{~g}$ (cigarettes)/week & 8 \\
\hline
\end{tabular}

a See footnote 4 of the text for an explanation of working-level month (WLM).

b All smokers from youth. 
Norwegian male population, was 2.96 cases (table 3 ). Twelve cases had occurred up to the end of 1981 . This value gives a ratio of observed to expected numbers of 4.05 ( $p<0.001$ one-tailed).

In table 4 the study group has been divided into three categories based on the estimated lifetime dose of tobacco in grams up to the end of 1981. The table shows an increasing lung cancer ratio with increasing tobacco dose. In 1964-1965 the Cancer Registry of Norway made a survey on the smoking habits of the Norwegian population (22). The smoking habits of the study group at the end of 1964 can therefore be compared with the results of this survey.

The survey showed that the percentage of current smokers and nonsmokers was 60 and 40, respectively, for the male population of Southeast Norway. In the present study group the percentage was 75 and 25 , and as high as 85 and 15 , respectively, for the underground miners. The relative distribution of heavy, medium, and light smokers in the study group was approximately the same as in the survey.

Table 5 shows the distribution of lung cancers in five categories of assessed cumulated alpha activity exposure in working-level months. The table shows a dose-related increase in the lung cancer rate.

Table 6 shows the 12 lung cancer cases with relevant exposure factors. All of these workers started work at the mine in middle age; only two were younger than 40 years. Three of them lived in the Fen area during the work period. The mean age of diagnosis among the 12 cases was 67.3 years.

Radiology reports in the 11 hospital records showed that seven of the cancers were centrally situated, and four were in the periphery of the lung. The pathology reports showed that eight of the cancers were probably small squamous cell carcinoma, and three were probably small cell carcinoma.

\section{Discussion}

The present study shows an association between lung cancer and cumulative alpha radiation exposure and also between lung cancer and smoking. However, some confounding factors have to be considered.

About 40 short-time workers employed before 1957 could not be identified. They had all been employed less than two years. Because of the limited exposures which would have been possible during a maximum of two years, all these workers would have belonged to the lower two categories for alpha radiation exposure. The missing persons could not, however, affect the results in the higher three exposure categories for radiation.

The reliability of the exposure data can be questioned. The assessment of the alpha radiation exposures were based on insufficient measurements, both in number and quality. Radon concentrations in mine air are known to show large spatial and temporal variations. The measurements were only per- formed during a 2 -d period at a few sites during the winter. During winter, the ventilation system was only used periodically. The temporal variations in the radon concentrations thus were probably large.

The measurement technique was also rather crude, and the uncertainties of the calibration procedure are not easy to assess. The dust concentration in the air was also very high at the time of the measurements, and the self-absorption in the filters could have been significant.

After the physicist who performed these measurements was consulted, the data on the alpha radiation exposure were reviewed. It then ensued that the minimum measurements in table 1 were made after a trial period of exceptionally good ventilation, which was not typical for the general work conditions in the mine.

It is therefore assumed that a mean level of $2 \mathrm{WL}$ radon daughters in the mine, in table 1 , is a more correct assessment than $1 \mathrm{WL}$. The calculated doses in tables 5 and 6 should therefore also be increased roughly by a factor of 2 to give a more correct appraisal.

Despite these limitations, we consider that major errors in the exposure characterization are unlikely to have occurred.

Other exposure factors may also have been of importance. The employees' place of residence at the time they worked at the mine was recorded, but no measurements of radiation in their homes were carried out. Measurements in some houses (21) in the area where the mine was situated have shown an exposure of up to $1.3 \mathrm{WLM} /$ year. Only 3 out of the 12 workers with lung cancer lived in the area of the mine at that time. The radiation in the homes, therefore, seems to be of limited importance.

The thorium content of the rocks might also have contributed to the radiation dose to the lungs. The critical tissues, however, are bone surfaces (9). As no bone cancers have appeared, there are so far no indications that this exposure has been of major importance.

It is also possible that other carcinogens may exist in the rocks mined. The mineral fiber content in one rock specimen from the site of the mine has been analyzed. Fibers compatible with actinolite were found, but these have not previously been associated with an increased risk of lung cancer. As it has not been possible to make further geochemical analyses of the rocks to search for possible carcinogenic elements, previous studies have been consulted $(5,14$, 15 ), but with negative results. A few of the workers were also exposed to diesel combustion exhaust, but, as the main mining activity was in the deep mine where the equipment was electrically driven, this factor seems to be of very little importance. The miners may occasionally have been heavily exposed to blasting gases, but it is difficult to assess the importance of this factor further. 
There were more smokers in the study group than in the reference population, and especially in the subcohort of miners, even though the distribution of light, moderate, and heavy smokers was identical. In accordance with estimations performed by Axelson (2), it is not likely that the smoking habits of the study cohort have contributed to a great extent to the increase in lung cancer cases.

It might have been more appropriate to use a local reference cohort rather than the national rates. The lung cancer incidence, in the county of Telemark where the mine was located, is about $90 \%$ of the national rates (6); therefore the national rates were used.

The longest follow-up period in this group was 28 years, and the shortest was 16 years. As cancers may occur after a considerably longer latency period, the numbers of the cancer cases are only preliminary. The assumed latency period for cancer development has not been subtracted from the calculation of the expected figures in this study; therefore the expected figures may have been overestimated (12).

When the factors to which the workers with lung cancer may have been exposed are considered (table 6), it can be assumed that for some cases the occupational exposure during previous employment may have been of importance. Three workers had been exposed to asbestos. Some of the cases in table $6 \mathrm{had}$ previous exposures to radon and thoron daughters in underground work. Case 3 worked as a blacksmith in an iron mine for nine years (1917-1926). Recent measurements in this mine suggest that the thoron daughter concentration was about $3 \mathrm{WL}$ and the radon daughter concentration about $0.1 \mathrm{WL}$ (21). It is assumed that the blacksmith spent about $30 \%$ of his workhours in this mine, and this figure indicates an exposure of about $30 \mathrm{WLM}$. This is significant exposure when compared to his exposure in the niobium mine.

Case 12 had worked 20 years in a molybdenum mine. The radon daughter concentration in that mine has been assessed to be about $0.2 \mathrm{WL}$ (17). Therefore the case involved a previous exposure of nearly 50 WLM.

The other cases with earlier underground exposures (cases 4, 6, and 8 ) were exposed in tunnels for limited periods. The radon daughter concentrations in tunnels are normally lower than in mines, and, in view of the relatively short exposure times, these exposures are hardly significant.

Table 1 indicates that the thoron daughter exposure to the workers at the mine was relatively low. After inhalation of thoron daughters, tissues at bone surfaces and in the kidneys are considered at greatest risk, together with lung tissues. This situation is in contrast to the inhalation of radon daughters, where only the lung is considered at greatest risk (11). In the present study group, no bone cancer and only one cancer of the kidney was found. This finding suggests that the thoron daughters seem to have contributed relatively little to the radiation hazard among the workers.

A commonly applied method for calculating risk among miners is to calculate the excess cases per million person-years (PY) at risk per WLM. After correction for the assumed underestimation of the alpha radiation level in the mine, the excess lung cancers for the exposed workers in the study group appears to be 50 cases $\cdot 10^{-6} \mathrm{PY}^{-1} \cdot \mathrm{WLM}^{-1}$. ICCR publication 32 (10) regards 5-15 cases $10^{-6} \mathrm{PY}^{-1}$. $\mathrm{WLM}^{-1}$ as the most probable range averaged over all age periods during occupational work. The risk, however, seems to be rather age-dependent, and the BEIR III report (8) concludes that for persons with age of diagnosis over 65 years a likely risk factor is about 50 cases $\cdot 10^{-6} \mathrm{PY}^{-1} \cdot \mathrm{WLM}^{-1}$. In the present material the mean age at diagnosis was 67.3 years.

The study has demonstrated an increase in the lung cancer incidence related to both the intensity of smoking and the alpha radiation dose.

\section{Acknowledgments}

The Norwegian Cancer Society and the Federation of Industries in Telemark have supported this work economically.

We thank Ms U Danielsen for her competent secretarial assistance and Ms P Flor for her linguistic guidance.

\section{References}

1. Archer VE. Health concerns in uranium mining and milling. J Occup Med 23 (1981) 502-505.

2. Axelson $O$. Aspects on confounding in occupationai health epidemiology. Scand J Work Environ Health 4 (1978) $98-102$

3. Axelson O. Epidemiologi för arbets- og miljömedicin. Studentlitteratur, Lund, Sweden 1981, p 64.

4. Axelson O. Epidemiology of occupational cancer: Mining and ore processing. In: International Labour Office. Prevention of occupational cancer: International symposium, proceedings, Helsinki $21-24$ April, 1981. Geneva 1982, pp 135-149. (Occupational safety and health series no 46).

5. Barth TFW, Ramberg IB. The Fen circular complex. In: Tuttle OF, Gittins J, ed. Carbonatites. Interscience, New York, NY 1966, pp 225-257.

6. Cancer Registry of Norway. Incidence of cancer in Norway 1972-1976. The Norwegian Cancer Society, Oslo 1978.

7. Cancer Registry of Norway. Trends in cancer incidence in Norway. Oslo 1982.

8. Committee on the Biological Effects of Ionizing Radiations. The effects of populations of exposure to low levels of ionizing radiation: 1980. National Academy Press, Washington, DC 1980. (BEIR III 1980).

9. International Commission on Radiological Protection. Limits for intake for radionuclides by workers. Pergamon Press, Oxford 1979. (ICRP publication 30).

10. International Commission on Radiological Protection. Limits for inhalation of radon daughters by workers. Pergamon Press, Oxford 1981. (ICRP publication 32). 
11. Jacobi W, Eiseld K. Dose to tissues and effective dose equivalent by inhalation of radon-222, radon-220 and their short-lived daughters. Gesellschaft für Strahlenund Umweltforschung, München-Neuherberg 1980.

12. Langård $\mathrm{S}$. The carcinogenicity of chromium compounds in man and animals. In: Burrows D, ed. Chromium: Metabolism and toxicity. CRC Press, Boca Raton, FA 1983, pp 13-30.

13. Langård $\mathrm{S}$, Norseth $\mathrm{T}$. $\mathrm{A}$ cohort study of bronchial carcinomas in workers producing chromate pigments. Br J Ind Med 32 (1975) 62-65.

14. Mitchell RH, Brunfelt AO. Scandium, cobalt and iron geochemistry of the Fen alkaline complex, Southern Norway. Earth Planet Sci Lett 23 (1974) 189-192.

15. Mitchell RH, Brunfelt AO. Rare earth element chemistry of the Fen alkaline complex, Norway. Contrib Mineral Petrol 52 (1975) 247-259.

16. Myers DK, Stewart CG, Johnson JR. Review of epidemiological studies on hazards of radon daughters. In: Gomez $\mathbf{M}$, ed. International conference: Radiation hazards in mining: Control, measurements, and medical aspects, October 4-9, 1981, Colorado School of Mines, Golden, CO (USA). American Institute of
Mining, Metallurgical, and Petroleum Engineers Inc, New York, NY 1981, pp 513-524.

17. Myran T. Radonmålinger i norske gruver. Bergverkenes landssammenslutnings industrigruppe, Trondheim 1973. (Teknisk rapport $\mathrm{nr} 27$ ).

18. Pedersen E, Högetveit AC, Andersen A. Cancer of respiratory organs among workers at a nickel refinery in Norway. Int $\mathbf{J}$ Cancer 12 (1973) 32-41.

19. Stokinger $\mathrm{HE}$. Niobium $\mathrm{Nb}$ (Columbium, $\mathrm{Cb}$ ). In: Clayton GD, Clayton FE, ed. Patty's industrial hygiene and toxicology. Volume 2A (Toxicology). Third edition. Wiley-Interscience, New York, NY 1981, pp $1841-1853$

20. Stranden E. Thoron and radon daughters in different atmospheres. Health Phys 38 (1980) 777-785.

21. Stranden E. En undersøkelse av naturlig stråling Fensfeltet ved Ulefoss. State Institute of Radiation Hygiene, Østerås, Norway 1982. (SIS Report 1982: 9).

22. Zeiner-Henriksen $T$. Røkevaner i den norske befolkning. Tidsskr Nor Laegeforen 96 (1976) 617-620.

Received for publication: 4 November 1983 